\title{
PERAN KATEKIS DALAM PENDIDIKAN POLITIK BAGI GENERASI MILENIAL PADA PERHELATAN PEMILU 2019
}

\author{
Oleh: Kristoforus Kopong
}

\begin{abstract}
Abstrak:
Pemilu adalah pengejawantahan kedaulatan rakyat. Dua fungsi pemilu yang saling berkaitan yaitu menciptakan sirkulasi dan seleksi pemimpin (elite politik) dan pendidikan politik warga negara. Menjelang pemilu serentak 2019 parpol maupun para kandidatnya memberikan perhatian lebih pada fungsi pemilu sebagai sarana untuk sirkulasi (seleksi) pemimpin dengan tekanan pada kekuasaan. Sedangkan fungsi pendidikan politik warga negara diabaikan begitu saja. Katekis sebagai warga Gereja sekaligus warga negara yang mengajar dan mendidik perlu memiliki sensitivitas politik dan berpartisipasi aktif di dalamnya dengan memberikan pendidikan politik bagi warga masyarakat terutama pada generasi milenial yang mana sebagian besar dari mereka adalah pemilih pemula. Melalui pendidikan politik generasi milenial akan mengerti dan memahami posisinya sebagai pemegang kedaulatan yang sangat menentukan gerak serta perjalanan bangsa dan negaranya.
\end{abstract}

Kata kunci: Katekis, Pendidikan Politik, Generasi Milenial.

\section{Pengantar}

$\mathrm{P}$ emilu adalah sebuah sebuah mekanisme politik untuk mengartikulasikan aspirasi dan kepentingan warga negara. Saat ini genderang pesta demokrasi sudah ditabukan dan perjalanan panjang menuju pemilihan umum 2019-pun semakin mendekat ke hari H. Semua persiapan pemilihan umum secara serentak, mulai dari Pemilihan Presiden (Pilpres) sampai Pemilihan Legislator (Pileg) sudah dilakukan sejak awal Agustus 2018. Dimulai dari pendaftaran bakal calon legislator (DPR, DPD dan DPRD), bakal calon Presiden dan Wakil Presiden, sampai pengesahan calon.

Sebagaimana Pemilu sebelum persiapan pesta rakyat selalu dihiasi dengan ribuan bahkan jutaan baliho para kandidat yang berjejer sepanjang ruas jalan baik di kota metropolitan maupun di desa dan kampung-kampung. Bahkan tidak jarang spanduk, umbul-umbul, baliho, atau yang disebut dengan Alat Peraga Kampanye (APK) dipasang pada titik-titik lokasi terlarang, khususnya di white area. Tidak cukup dengan itu para kandidat juga membagikan kalender dan kartu/foto kepada masyarakat calon konstituen untuk ditempelkan pada dinding rumah, kendaraan, bahkan di tiang-tiang listrik dan pepohonan. Bersamaan dengan itu para kandidat dari berbagai partai politik bersiliweran masuk-keluar daerah pemilihan (dapil) untuk mengempanyekan diri-rekam jejak, visimisi dan program kerjanya.

Fenomena cukup menarik yang mucul dari euforia pesta rakyat lima tahunan kali ini, yaitu di satu sisi adanya bonus demografi dimana generasi milenial menjadi penyumbang suara cukup banyak dalam Pemilu 2019. Berdasarkan data Komisi Pemilihan Umum (KPU), jumlah pemilih milenial mencapai 70 juta-80 juta jiwa dari 193 juta pemilih. Artinya, sekitar 35-40 persen memiliki pengaruh besar terhadap hasil 
pemilu dan menentukan siapa pemimpin pada masa mendatang. ${ }^{1}$ Sementara di sisi yang lain proses pendidikan politik bagi generasi milenial tidak dilakukan secara efektif.

Bagi pesta demokrasi kita, fenomena ini justru menjadi peluang sekaligus tantangan dalam pemilu serentak yang akan diselenggarakan pada 17 April 2019. Menjadi peluang karena generasi milenial dapat memberikan warna tersendiri dalam pemilu kali ini. Mereka sebagai generasi muda dapat menentukan masa depan bangsa dan negara ini melalui hak suaranya. Dan menjadi tantangan besar apabila generasi milenial itu tidak dibekali dengan pendidikan politik yang baik. Parpol dan para kandidatnya hanya sibuk melakukan manuver-manuver politik untuk mendapatkan dukungan, lalu melupakan tugas pokoknya untuk memberikan pendidikan politik kepada masyarakat umum secara khusus generasi milenial yang kebanyakan dari mereka adalah pemilih pemula.

Kealpaan parpol dan para kandidatnya dalam memberikan pendidikan politik kepada generasi milenial berbanding lurus dengan sosialisasi dan kampanye politik yang tidak elegan dan jauh dari etika politik. Isu apa pun termasuk SARA digoreng dengan maksud menyerang pihak yang berseberangan. Di samping itu black campaign, negative campaign, politic transactional dan hoaks politik membanjiri dunia maya hingga menyebar luas dan menyasar pemilih pemula. Hal ini tentu tidak sehat bagi keberlanjutan demokrasi dan masa depan Indonesia.

Berhadapan dengan situasi politik seperti itu, kita tidak bisa berharap banyak pada parpol. Sebagai warga Gereja dan warga negara, katekis tidak cukup hanya merasa prihatin dengan kondisi yang ada atau mempersalahkan parpol dan para kandidatnya. Katekis perlu memiliki horison politik sendiri yaitu "dari pada mengutuki kegelapan lebih baik menyalahkan lilin" dengan mengedukasi umat yang sekaligus masyarakat terutama generasi milenial dengan Pendidikan Politik. Hal ini dimaksudkan agar mereka mendapat pencerahan secara politik dan memiliki otonomitas dalam memberikan hak suaranya. Tapi apa peran katekis dalam pendidikan politik? Dimana lokus dan apa fokus pendidikan politik? Apa saja materi pendidikan politik? Apa metode dan media yang digunakan dalam pendidikan politik bagi generasi milenial? Oleh karena itu, tulisan sederhana ini berusaha untuk mencoba menjawab pertanyaan seputar Peran Katekis dalam Pendidikan Politik bagi Generasi Milenial.

\section{Katekis sebagai warga Gereja dan Warga Negara yang Mengajar}

Dalam konteks Gereja Katolik katekis adalah orang yang beriman yang dipanggil secara khusus dan diutus oleh Allah serta mendapat penugasan dari Gereja melalui missio canonika dari Gereja terutama dalam karya pewartaan untuk memperkenalkan, menumbuhkan dan mengembangkan iman umat di sekolah dan dalam komunitas basis, baik teritorial maupun kategorial. ${ }^{2}$ Dari pengertian ini dapat dipahami bahwa sosok Katekis adalah: pertama, seorang yang beriman Kristiani. Beriman Kristiani merupakan syarat mutlak (conditio sine qua non) bagi seorang katekis yang nantinya akan mewartakan Kristus. Kedua, Katekis dipanggil dan diutus oleh Allah untuk mewartakan Kabar Gembira. Allah merupakan inisiator dalam panggilan dan perutusan seorang katekis. Ketiga, Katekis mengemban tugas khusus dan utama

\footnotetext{
${ }^{1}$ Ahmad Nur Hidayat, "Beda Cara Generasi Milenial dalam Politik" dalam Harian Umum Flores Pos Edisi Selasa, 18 September 2018 No.7/XIX, hlm. 1

${ }^{2}$ Komisi Kateketik KWI, Identitas Katekis di Tengah Arus Perubahan Jaman (Jakarta: Komkat KWI, 2005), hlm. 133.
} 
mewartakan Yesus Kristus. Yesus Kristus dan karya-Nya merupakan inti pengajaran seorang katekis.

Dari sosok seorang katekis terdapat peran yang amat sentral dalam pewartaan Gereja tentang Yesus Kristus. Dokumen Pedoman Untuk Katekis yang diterbitkan Kongregasi Evangelisasi Bangsa-Bangsa merumuskan peran Katekis yaitu menyampaikan secara jelas pesan Kristiani mengenai para katekumen dan orang-orang Kristen yang baru dibaptis dalam perjalanan hidupnya menuju kedewasaan iman serta kehidupan sakramental penuh". ${ }^{3}$ Lebih lanjut dalam Pertemuan Nasional Katekis 2005 di Jakarta, mendiskusikan mengenai identitas katekis di tengah Arus Perubahan Jaman. Salah satu yang didiskusikan Regio Kalimantan, Katekis jaman ini memiliki peran untuk memperkenalkan dan menuntun sesama umat untuk menumbuhkan iman melalui komunitas basis dalam situasi konkret. ${ }^{4}$ Regio Sumatera merumuskan peran Katekis saat ini untuk menumbuhkan dan mengembangkan kelompok basis, supaya menghayati dan mengungkapkan imannya bersama umat basis dalam peziarahannya. Selain itu Katekis berperan sebagai pewarta sabda dan petugas pastoral. ${ }^{5}$ Regio Nusra merumuskan peran Katekis yang dibutuhkan saat ini adalah membangun dan mengembangkan communio baik dalam lingkup teritorial maupun kategorial. ${ }^{6}$ Regio Jawa merumuskan peran Katekis yakni mendampingi hidup umat beriman. ${ }^{7}$ Dari peran yang dikemukakan oleh Komkat KWI di atas dapat disimpulkan bahwa peran katekis sebagai pengajar yang mengajarkan iman akan Yesus Kristus, membangun, mengembangkan dan mendampingi hidup umat beriman basis di dalam pewartaan sabda dan pelayanan pastoral.

Dalam perspektif sebagai warga negara katekis juga disebut sebagai pengajar/pendidik. Pendidik adalah tenaga kependidikan yang berkualifikasi sebagai guru, dosen, konselor, pamong belajar, widyaiswara, tutor, instruktur, fasilitator, dan sebutan lain yang sesuai dengan kekhususannya, serta berpartisipasi dalam menyelenggarakan pendidikan. ${ }^{8}$ Peran katekis sebagai pendidik dapat dilakukan baik dalam satuan pendidikan pada jalur formal dengan berperan sebagai guru agama, sedangkan pada nonformal dan informal berperan sebagai katekis.

Katekis bukan hanya sekedar pengajar agama dan katekese, tetapi juga panutan (role model) bagi umat beriman. Maka, segala tindakan dan perkataan katekis harus sesuai dengan ajaran Yesus sendiri. Seperti Yesus yang bukan hanya mengajar melalui kata-kata tetapi perannya sebagai model teladan hidup seorang yang dekat dengan Allah. Demikian juga katekis memainkan perannya sebagai teladan kehidupan umat beriman Kristiani dan juga masyarakat di sekitarnya.

\section{Pemilu Serentak-2019 sebagai Lokus Pengajaran Katekis}

Pewartaan Sabda Allah adalah bagian penting dari tugas pokok Gereja. Pewartaan Sabda Allah adalah juga tugas dari semua umat beriman sebagai murid-murid Kristus termasuk katekis. Hal itu diperintahkan oleh Kristus kepada murid-muridNya: "Pergilah jadikanlah semua bangsa murid-Ku dan baptislah mereka dalam nama Bapa

\footnotetext{
${ }^{3}$ Komisi Kateketik KWI, Pedoman Untuk Katekis (Yogyakarta: Kanisius, 1997), hlm. 16.

${ }^{4}$ Komisi Kateketik KWI, Op.Cit., hlm. 125.

${ }^{5}$ Ibid., hlm. 126.

${ }^{6}$ Ibid., hlm. 128.

${ }^{7}$ Ibid., hlm. 130

${ }^{8}$ Pasal 1 ayat (1) Undang-Undang No. 20 Tahun 2003 Tentang Sistem Pendidikan Nasional
} 
dan Anak dan Roh Kudus, dan ajarlah mereka melakukan segala sesuatu yang telah kuperintahkan kepadamu” (Mat. 28,19). Lebih jelas dan terang lagi dalam Markus 16, 15-16: "Pergilah ke seluruh dunia, beritakanlah Injil kepada segala makhluk. Siapa yang percaya dan dibaptis akan diselamatkan tetapi siapa yang tidak percaya akan dihukum". Perintah "Pergilah ke seluruh dunia..." dalam -misi perutusan Yesus di atas tidak hanya dimengerti dalam aspek kewilayahan seperti geografis dan topografis, tetapi juga mesti dapat dipahami dalam konteks suasana/situasi tertentu seperti demokrasi dan politik.

Dewasa ini demokrasi telah menjadi kredo bagi sebagian besar warga dunia termasuk Indonesia sebagai cara terbaik dalam mengelola kehidupan bersama dalam wadah sebuah negara. Andrian Karatnycky menyebutkan sebagian besar negara di dunia saat ini telah memenuhi standar minimal demokrasi, yaitu memenuhi syarat bahwa wakil rakyat di pemerintahan dipilih melalui pemilu secara periodik, kompetitif, bebas, dan jujur di mana hampir semua warga negara dewasa mempunyai hak memberikan suara. ${ }^{9}$

Dalam perspektif historis cita-cita atau ide demokrasi di Indonesia dimunculkan oleh para the founding fathers bangsa. ${ }^{10}$ Dan dalam perjalanan yang panjang hingga saat ini Indonesia sebagai negara demokrasi telah menyelenggarakan pemilu secara rutin 5 tahun sekali, yaitu 1955, 1971, 1977, 1982, 1987, 1992, 1997, 1999, 2004, 2009, 2014. Menurut para pakar dan pengamat politik dari beberapa kali pemilu, pemilu 1955 dinilai sebagai pemilu paling demokratis dan bersih, karena berlangsung aman di saat kondisi keamanan negara sedang tidak kondusif. Dengan lain perkataan, pemilu pertama itu telah menjadi semacam tipe ideal yang harus dipakai sebagai rujukan atau referensi utama bagi pelaksanaan pemilu berikutnya. ${ }^{11}$ Saat itu Indonesia sedang mengalami kekacauan, di Madiun misalnya,tengah terjadi pemberontakan yang dilakukan oleh kelompok DI/TII (Darul Islam/Tentara Islam Indonesia) yang dipimpin oleh Kartosuwiryo.

Konteks yang sedang dihadapi oleh bangsa dan negara Indonesia saat ini adalah suasana atau situasi politik yang sedang memanas menjelang Pemilu Serentak 2019. Panggung politik dan ruang demokrasi saat ini dipenuhi isu-isu politik yang merebak sampai ke masyarakat akar rumput, seperti isu SARA, black campaign, negative campaign, dan hoaks politik. Politik yang pada hakekatnya merupakan sesuatu yang baik-untuk kebaikan, namun secara faktual politik saat ini sudah dipenuhi dengan keburukan, penuh persaingan tidak sehat, pertentangan dan perpecahan, serta dijadikan sebagai alat untuk kepentingan diri sendiri atau kelompok. Wacana politik telah mengembara jauh ke dalam peradaban manusia lalu tampil sebagai monster yang tidak beradab. $^{12}$

Situasi itu bisa menghambat penyelenggaraan pemilu sebagai wujud demokrasi. Hasil survei LIPI mengatakan ada potensi yang bisa menghambat penyelenggaraan pemilu serentak 2019. Paling tinggi politisasi SARA dan identitas mencapai $23,6 \%$. Kedua, konflik horizontal antar-pendukung 12,3\%, gangguan keamanan 10,4\%, kurang

\footnotetext{
${ }^{9}$ Bambang Sulasmono, Pendidikan Kewarganegaraan (Salatiga: FKIP-UKSW, 2001), hlm. 62.

${ }^{10}$ Franz Magnis Suseno, Etika Dasar: Masalah-Masalah Pokok Filsafat Moral (Yogyakarta: Kanisius, 1997), hlm. 9-10.

${ }^{11}$ Muhammad A.S. Hikam, Politik Kewarganegaraan: Landasan Redemokratisasi di Indonesia (Jakarta: Penerbit Erlangga, 1999), hlm. 16.

${ }^{12}$ Bdk. Kristoforus Kopong, “Optimalisasi Peran Gereja Katolik di Bidang Politik” dalam Atma Reksa-Jurnal Pastoral dan Kateketik Vol. II, No. 2. Edisi Juli-Desember 2017, hlm. 52
} 
siap penyelenggara pemilu $6,6 \%$, ketidaknetralan penyelenggara pemilu $5,7 \% .{ }^{13} \mathrm{Hal}$ ini menimbulkan kecemasan bagi masyarakat Indonesia sebagai "tuan" dalam pesta demokrasi lima tahunan itu.

Realitas sosial politik menjelang pemilu 2019 di atas dapat menjadi lokus baru bagi pewartaan seorang Katekis. Dalam lokus yang baru ini katekis dengan perannya sebagai pendidik menjadi garam dan terang. Kepada para pengikutnya termasuk katekis, Yesus pernah berkata: "Kamu adalah garam dan terang dunia" (bdk. Mat. 5:14-15). Sebagai garam katekis perlu menggarami situasi politik yang sudah mulai membusuk dan sebagai terang katekis perlu menerangi lorong-lorong politik yang gelap. "Kebusukan" dan "kegelapan" merupakan lambang dari situasi politik yang sudah jauh dari hakikatnya dan telah menimbulkan keresahan dalam hidup bersama sebagai sebuah bangsa dan negara yang demokratis.

Dalam lokus politik seperti itu, katekis tidak boleh diam tetapi sebagai pengajar/pendidik tetap mengupayakan cara dan strategi yang efektif untuk menggarami dan menerangi situasi politik yang carut-maruk. Hal ini tentu didasari oleh pemaknaan Gereja Katolik sebagai bagian dari pengalaman umat manusia akan kegembiraan, sukacita, harapan serta duka dan kecemasan sehari-hari, sebagaimana dirumuskan GS 1: "Kegembiraan dan harapan, duka dan kecemasan orang-orang zaman sekarang, terutama kaum miskin dan siapa saja yang menderita merupakan kegembiraan dan harapan, duka dan kecemasan para murid Kristus juga". ${ }^{14}$

Pernyataan Konsili Vatikan II itu mereflesikan adanya keterbukaan luar biasa dari pihak Gereja Katolik secara khusus Katekis dalam tugas pewartaannya dalam kehidupan publik. Karena itu, Katekis dalam perannya perlu tampil membantu dan mendidik masyarakat supaya bisa mendefinisikan dirinya sendiri sebagai agen pembaharu yang mampu membebaskan diri dari situasi politik yang dihadapi dengan kekuatannya sendiri. Dengan demikian politik dengan segala problematikanya bukan menjadi wilayah yang asing bagi katekis, melainkan lokus pengajaran yang sangat kontekstual untuk mewartakan kabar gembira keselamatan Allah bagi manusia dan dunia. Keterlibatan Katekis dalam pendidikan politik merupakan sebuah panggilan dan perutusan; yang dalam kacamata iman dapat dilihat sebagai perwujudan dari iman akan Yesus Kristus.

\section{Generasi Milenial sebagai Fokus (Sasaran) Pendidikan Politik Katekis}

Ruang lingkup politik yang menjadi lokus pengajaran seorang katekis sangat luas. Karena itu agar pengajaran dan pewartaannya lebih efektif dan efisien, maka seorang katekis perlu membatasi diri dan fokus pada kelompok sasar tertentu. Kelompok sasar yang menjadi fokus perhatian katekis dalam pendidikan politik yaitu generasi milenial. Pertanyaannya "siapa itu Generasi milenial dan mengapa harus Generasi milenial?"

Generasi Milenial adalah terminologi generasi yang saat ini banyak diperbincangkan oleh banyak kalangan di dunia di berbagai bidang termasuk politik. Generasi Milenial (juga dikenal sebagai Milenials atau Generasi Y) adalah kelompok demografis (cohort) setelah Generasi X. Peneliti sosial sering mengelompokkan

13 NN,https://nasional.kompas.com/read/2018/08/07/12084651/potensi-politisasi-sara-danidentitas-akan-hambat-pemilu-2019 (diakses, 18 Desember 2018).

${ }^{14}$ R. Hardawiryana (Penterj), Dokumen Konsilivatikan II (Jakarta: Obor, 1993), hlm. 509. 
generasi yang lahir diantara tahun 1980-an sampai 2000-an sebagai Generasi Milenial. Jadi bisa dikatakan generasi milenial adalah generasi muda masa kini yang saat ini berusia dikisaran $15-34$ tahun. ${ }^{15}$

Selanjutnya Generasi Milenial menjadi sangat penting dalam konteks perhelatan politik 2019 karena beberapa alasan berikut:

Pertama, dari sisi kuantitas sebagian besar pemilih pemilu 2019 adalah generasi milenial. Dari total pemilih 195 juta pemilih, sekitar 85 juta di antaranya adalah pemilih milenial atau lebih dari 40 persen. Atau berdasarkan perhitungan KPU, jumlah pemilih milenial mencapai 70 juta-80 juta jiwa dari 193 juta pemilih atau sekitar 35-40\%. Prosentase ini amat berpengaruh terhadap hasil pemilu dan menentukan siapa pemimpin pada masa mendatang.

Kedua, secara psikologis millennial voters adalah juga emotional voters yang sering galau (ikut-ikutan). Karena itu, sentuhan emosional (emotional hijacking) atau personal branding si kandidat pada hari-hari menjelang pemilu serentak dapat saja "menyandera" pikiran rasional Gerenrasi Milenial. "Millennial-friendly" menjadi senjata pamungkas untuk memenangkan persaingan dalam memperebutkan suara Generasi Milenial.

Ketiga, karakter yang menonjol dari generasi millennial adalah mereka tidak memiliki loyalitas yang tinggi terhadap institusi termasuk partai. Karena itu, dapat dipahami jika mereka tidak mudah tunduk dan patuh terhadap garis instruksi. Generasi milenial hanya akan mau didekati dan dirangkul dengan cara yang kreatif, dengan bahasa yang mereka gunakan, dan melalui jalur komunikasi yang biasa mereka sering gunakan.

Keempat, dalam hal penguasaan ilmu pengetahuan, teknologi dan seni (ipteks). Berbeda dengan generasi sebelumnya (Generasi X), Generasi milenial (Generasi Y) adalah generasi yang sangat melek dengan teknologi terutama dengan internet dan haus akan dunia hiburan (entertainment). Keunikan dan kebutuhan Generasi Milenial inilah yang sering memaksa selebriti menjadi politisi dan politisi menjadi selebriti.

Generasi milenial dengan segala karakteristiknya menjadi segmen pasar baru bagi partai politik untuk mendulang suara pada Pemilu 2019 mendatang. Mereka dapat saja menjadi sasaran empuk partai politik dan para kandidat yang masuk dalam bursa pemilu 2019. Generasi milenial dengan segala potensinya tidak lebih hanya dijadikan obyek dalam percaturan politik di tanah air. Otonomitas generasi milenial dalam memberikan hak suaranya "dibajak" oleh manuver partai politik dan kandidatnya dalam mencapai tujuan mendapatkan kekuasaan (will to the power).

Padahal secara yuridis Undang-Undang No. 2 tahun 2008 yang kemudian direvisi menjadi Undang-Undang No. 2 tahun 2011) tentang Partai Politik, mengamanatkan bahwa partai politik melaksanakan pendidikan politik. Pengenalan politik sebenarnya sudah menjadi keharusan oleh partai politik. ${ }^{16}$ Rakyat terutama Generasi Milenial harus mendapatkan pendidikan politik sesuai sebelum memberikan suara untuk menentukan pilihan dalam setiap pemilu. Namun perintah undang-undang tersebut sering diabaikan begitu saja oleh partai politik.

\footnotetext{
${ }^{15} \mathrm{NN}$ ' https://id.wikipedia.org/wiki/Milenial, (diakses, 18 Desember 2018).

${ }^{16}$ Pasal 11 Undang-Undang No. 2 Tahun 2011 Tentang Partai Politik
} 
Kondisi sosio-politik seperti ini, harus menggugah nurani Katekis sebagai pengajar untuk menjadikan Generasi milenial sebagai fokus dalam pewartaannya. Dalam perannya sebagai pewarta Sabda Allah katekis harus memandang Generasi milenial sebagai Citra Allah, sehingga dengan mata iman ia dapat menepatkan mereka sebagai sasaran atau fokus dalam pendidikan politik. Hanya dalam prespektif iman katekis dapat mengangkat martabat Generasi milenial dan menempatkannya sebagai subyek yang otonom dan independen dalam menentukan hak suaranya dalam pemilu 2019 nanti.

\section{Ajaran Gereja dan Nilai Universal sebagai Substansi Pendidikan Politik Katekis}

Generasi milenial akan tampil sebagai subyek yang otonom (independent) atau tidak dalam menentukan hak suaranya dalam pemilu 2019 nanti tergantung pada sejauhmana mereka dibekali dengan pendidikan politik. Mustahil jika Generasi milenial yang sebagian besar adalah pemilih pemula dapat memilih dengan sadar dan/atau rasional bila tidak memahami politik. Jika demikian pengenalan politik menjadi awal amat menentukan pilihan sadar dan rasional itu. Di sini peran khas Ketekis dalam memberikan pendidikan politik kepada Generasi milenial menjadi sangat penting. Pertanyaannya apa substansi pendidikan politik yang diberikan Katekis kepada Generasi milenial?

Subastansi pendidikan politik yang diberikan pertama-tama tentu hal yang berkaitan langsung dengan tugas pokok Katekis. Tentang tugas pokok katekis, KHK, 1983 kan. 773 menegaskan: "menjadi tugas khusus dan berat, terutama bagi para gembala rohani, untuk mengusahakan katekese umat kristiani agar iman kaum beriman melalui pengajaran agama dan melalui pengalaman kehidupan kristiani, menjadi hidup, disadari dan penuh daya". Jadi tugas pokok katekis adalah mewartakan Sabda Allah melalui pengajaran agama (katekese), membagi pengalaman hidup kristiani, dan penghayatan hidup beriman. Oleh karena itu, bagi Katekis subsatansi pendidikan politik bagi Generasi milenial adalah Injil yang telah menjadi ajaran Gereja.

Kedua, dalam perspektif katekis sebagai warga negara substansi pendidikan politik yang dapat diberikan kepada generasi milenial adalah hal-hal yang berkaitan dengan kehidupan bersama sebagai warga bangsa dan negara Indonesia. Pasal 1 ayat (4) Undang-Undang No. 2 Tahun 2011 tentang Partai Politik. Pasal ini menyebutkan bahwa "pendidikan politik adalah proses pembelajaran dan pemahaman tentang hak, kewajiban dan tanggung jawab setiap warga negara dalam kehidupan berbangsa dan bernegara". Jadi substansi pendidikan politik dalam perspektif ini adalah seputar masalah hak, kewajiban dan tanggung jawab setiap warga negara.

Sehubungan dengan materi Pendidikan Politik Peraturan Menteri Dalam Negeri No. 36 Tahun 2010 tentang Fasilitasi Penyelenggaraan Pendidikan Politik, Pasal 11 ayat (2) menegaskan bahwa materi pendidikan, meliputi materi wajib dan materi pilihan. Materi wajib meliputi: (a) Pancasila; dan (b) Undang-Undang Dasar Negara Republik Indonesia Tahun 1945. Sedangkan materi pilihan antara lain: (a) demokrasi; (b) hak asasi manusia; (c) sistem pemerintahan; (d) pertahanan dan keamanan; (e) budaya dan etika politik; (f) kebijakan publik; (g) pendidikan kewarganegaraan; (h) politik kesejahteraan sosial; (i) politik tata ruang dan lingkungan; (j) kepemerintahan yang baik; (k) globalisasi dan politik luar negeri Indonesia; (l) partai politik; (m) otonomi daerah; (n) masyarakat sipil; dan (o) pasar dan dunia usaha. 
Pelbagai materi pendidikan politik tersebut harus dapat digunakan sedemikian untuk dapat mencapai tujuan pendidikan politik bagi Generasi milenial antara lain: pertama, meningkatkan kesadaran hak dan kewajiban Generasi Milenial dalam kehidupan bermasyarakat, berbangsa, dan bernegara; Kedua, meningkatkan partisipasi politik dan inisiatif Generasi Milineial dalam kehidupan bermasyarakat, berbangsa, dan bernegara; dan Ketiga, meningkatkan kemandirian, kedewasaan, dan membangun karakter bangsa dalam rangka memelihara persatuan dan kesatuan bangsa. Keempat, meningkatkan pengetahuan politik Generasi Milenial agar mereka dapat berpartisipasi secara maksimal dalam sistem politik.

Keempat tujuan pendidikan politik di atas sejalan dengan Instruksi Presiden No. 12 Tahun 1982 tentang Pendidikan Politik bagi Generasi Muda yang menyatakan bahwa tujuan pendidikan politik adalah memberikan pedoman kepada generasi muda Indonesia guna meningkatkan kesadaran kehidupan berbangsa dan bernegara berdasarkan Pancasila dan Undang-Undang Dasar Negara Republik Indonesia Tahun 1945 sebagai salah satu usaha untuk membangun manusia Indonesia seutuhnya. Pendidikan politik juga merupakan bagian proses perubahan kehidupan politik bangsa Indonesia agar tercipta suatu sistem politik yang benar-benar demokratis, stabil, efektif dan efisien demi mencapai kesejahteraan bersama.

Maksud pendidikan politik di atas adalah untuk membangun etika dan budaya politik Generasi Milenial sesuai dengan Pancasila dan Undang-Undang Dasar Negara Republik Indonesia Tahun 1945. Sila-sila pancasila mengandung nilai-nilai universal seperti Ketuhanan, Kemanusiaan, Persatuan, Kerakyatan dan Keadilan. Hal ini didukung oleh Gereja yang ditandai dengan sikap Gereja dan umat Katolik yang menerima Pancasila dalam hidup bermasyarakat, berbangsa dan bernegara. Alasan Gereja dan umat Katolik menerima Pancasila, yaitu pertama, Pancasila yang mengandung nilainilai dasar yang manusiawi dapat menjadi pemersatu bangsa Indonesia yang sangat majemuk dan plural; Kedua, Nilai-nilai Pancasila merupakan nilai-nilai dasar hidup manusiawi yang sejalan dengan nilai yang diajarkan dan pandangan gereja Katolik; dan Ketiga, Pancasila yang bersumber dari nilai-nilai budaya dan sejarah hidup bangsa Indonesia yang majemuk telah diterima dan menjadi kesepakatan bersama Bangsa Indonesia sebagai pandangan hidup bangsa dan sebagai dasar hidup bernegara.

Pada titik inilah Agama (Gereja Katolik) dan Negara dari otonomitasnya masingmasing akhirnya harus bertemu dan bersinergi untuk melayani manusia yang sama. Menurut GS 74:

Negara merupakan wadah kebersamaan seluruh warga negara demi kepentingan umum berdasarkan kodrat manusia dan sesuai dengan kehendak Sang Pencipta. Demi keterarahan kepentingan umum itulah dibutuhkan lembaga yang memiliki wewenang dan kekuasaan. Warga wajib taat kepada wewenang dan kekuasaan yang mencita-citakan dan menjamin kesejahteraan umum. ${ }^{17}$

Di sini Katekis sebagai warga Gereja dan warga negara diberi peran dan tanggung jawab untuk mengajar dan membimbing perlu mengelaborasikan ajaran Gerja dan nilai-nilai universal dalam kehidupan bernangsa dan bernegara menjadi muatan pendidikan politik bagi Generasi Milenial. Pengelaborasian ini tidak hanya sekedar untuk kepentingan politik sesaat tetapi lebih dari itu untuk membangun fondasi

${ }^{17}$ R. Hardawiryana, Op.Cit. 
(karakter) dalam kehidupan berbangsa dan bernegara untuk kesejahteraan rakyat. Hal ini menjadi prinsip utama Gereja dan pegangan Katekis dalam proses pendidikan politik maupun dalam praksis berpolitik adalah seperti yang dikatakan oleh Bapak J. Kasiomo: "Salus Populi Suprema Lex" (Kesejahteraan rakyat adalah hukum yang tertinggi). Untuk itu materi pendidikan politik yang diberikan oleh katekis kepada generasi milenial harus mengandung dimensi penghormatan terhadap martabat manusia (HAM), kebebasan, keadilan, solidaritas, subsidiaritas, demokratis, kesetaraan, keberpihakan kepada kaum miskin, memiliki cita rasa dan tanggung jawab terhadap keutuhan ciptaan dan lingkungan hidup, serta memperjuangkan hak untuk memiliki pekerjaan demi hidup yang layak dalam masyarakat. ${ }^{18}$

\section{Katekese sebagai Metode dan Sosial Media sebagai Media Pendidikan Politik}

Keberhasilan pendidikan politik tidak terlepas dari pilihan metode dan media yang digunakan dalam proses pendidikan tersebut. Begitu juga dengan pendidikan politik yang dilakukan Katekis terhadap generasi milienial. Di sini Katekis perlu selektif, sehingga dapat memilih dan menggunakan metode dan media pendidikan politik yang tepat. Dengan demikian substansi materi pendidian politik dapat tersampaikan secara baik kepada Generasi milenial.

Metode pendidikan yang digunakan untuk menunjang keberhasilan pendidikan politik bagi generasi milenial adalah katekese. Berkaitan dengan hal ini Evangelii Nuntiandi memandang katekese sebagai bagian dari evangelisasi untuk pewartaan Sabda Kehidupan dan untuk menjadikan orang-orang manusia baru (EN 22). ${ }^{19}$ Oleh karena itu, dalam refleksi kateketis masa kini, katekese dipahami sebagai metode perjumpaan manusia dengan Allah yang terjadi melalui refleksi yang mendalam atas pengalaman manusiawi, personal dan sosial. Di sini katekese berperan untuk menginterpretasikan pengalaman personal, sosial dan eklesial dalam terang Sabda Allah yang mengarah kepada penerimaan rencana Allah dan mewujudkannya secara konkrit dalam pembaruan dunia yang lebih baik. ${ }^{20}$

Selain metode, media pendidikan politik Generasi muda merupakan aspek yang tidak boleh diabaikan begitu saja. Secara umum media yang digunakan dalam pendidikan politik terdapat dua model, yaitu media langsung dan media tidak langsung. ${ }^{21}$ Pertama, media langsung. Dengan media ini, Generasi milenial terlibat secara langsung, kritis dan otonom dalam proses-proses pendidikan yang dilaksanakan. Media ini misalnya berbentuk diskusi, pelatihan, workshop, debat terbuka, yang semuanya diarahkan pada materi-materi pendidikan. Dalam konteks ini katekese selain sebagai metode juga dapat dipakai pandang sebagai media. Kelebihan media ini adalah, ia lebih efektif dan berhasil dalam mencapai sasaran atau tujuan pendidikan politik, karena media ini biasanya dilaksanakan untuk jumlah terbatas dan kelompok terbatas (kelompok kategorial). Sedangkan kelemahannya adalah media ini tidak dapat mencapai tujuannya secara cepat dalam ukuran massal.

\footnotetext{
${ }^{18}$ Bdk. Nota Pastoral KWI, 2003.

${ }^{19}$ R. Hardawiryana, Op.Cit.

${ }^{20}$ Manfred Habur, "Katekese Keluarga di Era Digital" dalam Atma Reksa Jurnal Pastoral dan Kateketik Vol. I, No. 2. Edisi Juli-Desember 2016, hlm, 19 2017), hlm. 33 .

${ }^{21}$ Eko Handoyo dan Puji Lestari, Pendidikan Politik (Yogyakarta: Penerbit Pohon Cahaya,
} 
Kedua, media tidak langsung merupakan media dimana Generasi milenial tidak terlibat secara langsung dalam proses pendidikan politik. Media ini biasanya dipakai dalam proses pendidikan politik yang dilaksanakan secara massal dengan tujuan membangkitkan kesadaran generasi milenial atau memberi informasi penting kepada mereka tentang isi publik tertentu yang harus diperhatikan bersama. Media ini tidak dimaksudkan untuk membangun kecakapan atau keahlian tertentu generasi milenial namun sebatas pada menggugah kesadaran atau memberikan informasi. Media ini digunakan misalnya untuk menyebarkan informasi secara massal misalnya membuat spanduk, selebaran, leaflet, newsletter, memasang iklan di media massa, menyebarkan informasi lewat internet (media sosial,seperti facebook, twitter, instagram, SMS, WA, Line, dan berbagai aplikasi lain), dan sebagainya. Media tidak langsung terutama media sosial kelebihannya dapat menjangkau dan menembus semua populasi generasi milenial yang melek teknologi. Sedangkan kelemahannya tidak dapat berkomunikasi langsung seperti diskusi, pelatihan, workshop, debat terbuka, dan katekese pada media langsung.

Berdasarkan uraian di atas, Katekis sebagai pendidik politik harus kreatif dalam menggunakan metode dan media pendidikan bagi generasi milenial. Dengan metode dan media yang tepat katekis dapat membatu generasi milenial untuk memahami secara benar situasi politik menjelang pemilu serentak 2019. Selanjutnya generasi milenial pun dapat dapat berpartisipasi secara aktif dalam bidang politik sebagai pribadi yang otonom. Karena partisipasi yang otonom dalam pemilu 2019 hanya dapat dimungkinkan jika generasi milenial sebagai warga negara cukup terdidik secara politik.

Akhirnya, dalam konteks pemilu 2019 sebagai pengejawantahan kedaulatan rakyat, Generasi milenial harus dapat memilih sosok pemimpin (Presiden-Wakil, DPR, DPD dan DPRD) yang memiliki iman yang matang, bukan sekedar beragama. Karena masyarakat Indonesia yang religius sangat membutuhkan pemimpin yang mengabdi pada masyarakat, yang dijiwai dan dituntun oleh nilai, prinsip, visi dan misi yang tidak bertentangan dengan agama, Pancasila dan peraturan perundang-undangan yang berlaku. Nilai-nilai seperti: rendah hati, sabar, sederhana, peduli, rela berbagi, tidak marah dan dendam, penuh kasih adalah nilai-nilai universal yang amat kristiani (bdk. Kor. 13:1-2). .

\section{Penutup}

Menjelang pemilu 2019 pendidikan politik bagi generasi milenial merupakan bagian yang amat penting dan tidak boleh dilupakan dalam proses berdemokrasi. Sebab mereka adalah pemilik dan sekaligus masa depan bangsa dan negara. Oleh karena itu, mereka perlu mendapatkan pendidikan politik yang memadai, sehingga dapat menemukan jati diri (the recovery of identity) sebagai tulang punggung gereja, bangsa dan negara yang terlibat secara sadar dan kritis dalam pesta demokrasi lima tahunan itu.

Dalam kerangka ini, katekis sebagai pendidik perlu berperan aktif dan bila perlu pro aktif dalam proses pendidikan politik bagi generasi milenial. Sebagai pendidik politik bagi generasi milenial, Katekis perlu memiliki perspektif dan dimensi pedagogis yang mumpuni tentang lokus, fokus, dan materi serta metode dan media dalam pendidikan politik. Lebih dari itu, pendidikan politik bagi generasi muda juga harus bernuansa millennial-friendly, sehingga dapat mengembangkan kemampuan koginitif, afektif dan psikomotorik. Generasi milenial yang terdidik secara politik dapat berpikir rasional, bersikap mandiri dan bertindak otonom dalam bidang politik terutama dalam menentukan calon legislatif dan calon presiden dan wakil presiden pada pemilu 2019. 


\section{Daftar Kepustakaan}

\section{Buku-buku}

Habur, Manfred. "Katekese Keluarga di Era Digital” dalam Atma Reksa-Jurnal Pastoral dan Kateketik Vol. I, No. 2. Edisi Juli-Desember 2016.

Handoyo, Eko dan Puji Lestari. 2017. Pendidikan Politik. Yogyakarta: Penerbit Pohon Cahaya.

Hardawiryana, R. (Penterj). 1993. Dokumen Konsili Vatikan II. Jakarta: Obor.

Hidayat, Ahmad Nur. 2018. "Beda Cara Generasi Milenial dalam Politik" dalam Harian Umum Flores Pos Edisi Selasa, 18 September 2018 No.7/XIX.

Hikam, Muhammad A.S. 1999. Politik Kewarganegaraan: Landasan Redemokratisasi di Indonesia. Jakarta: Penerbit Erlangga.

Komisi Kateketik KWI. 1997. Pedoman Untuk Katekis. Yogyakarta: Kanisius.

Komisi Kateketik KWI, 2005. Identitas Katekis di Tengah Arus Perubahan Jaman. Jakarta: Komkat KWI.

Kopong, Kristoforus. 2017. "Optimalisasi Peran Gereja Katolik di Bidang Politik" dalam Atma Reksa-Jurnal Pastoral dan Kateketik Vol. II, No. 2. Edisi JuliDesember.

Republik Indonesia, Instruksi Presiden No. 12 Tahun 1982 tentang Pendidikan Politik bagi Generasi Muda.

Republik Indonesia, Peraturan Menteri Dalam Negeri No. 36 Tahun 2010 tentang Fasilitasi Penyelenggaraan Pendidikan Politik.

Republik Indonesia, Undang-Undang No. 20 Tahun 2003 Tentang Sistem Pendidikan Nasional.

Republik Indonesia, Undang-Undang Nomor 2 Tahun 2011 Tentang Partai Politik.

Sulasmono, Bambang. 2001. Pendidikan Kewarganegaraan. Salatiga: FKIP-UKSW.

Suseno, Franz Magnis. 1997. Etika Dasar: Masalah-Masalah Pokok Filsafat Moral. Yogyakarta: Kanisius.

\section{$\underline{\text { Internet }}$}

https://nasional.kompas.com/read/2018/08/07/12084651/potensi-politisasi-sara-danidentitas-akan-hambat-pemilu-2019 (diakses tanggal 18 Desember 2018).

https://id.wikipedia.org/wiki/Milenial, (diakses tanggal 18 Desember 2018) 